\title{
Skanner kan bidra til å redusere antallet trykkskader
}

\section{SEM-skanneren kan identifisere $\varnothing$ dem som utvikles i underliggende vev. Dermed kan den oppdage og forebygge usynlige trykkskader tidlig.}

\section{Ida Marie Bredesen}

Sykepleier, forsker og førsteamanuensis

Ortopedisk klinikk, Oslo universitetssykehus, Ullevål og Institutt for sykepleie- og helsevitenskap, Universitetet i Sørøst-Norge

\section{Ingebjørg Irgens}

Lege

Sunnaas sykehus

\section{Antonija Petosic}

Intensivsykepleier og stipendiat

Oslo universitetssykehus, Ullevål, Kirurgisk serviceklinikk, Haukeland universitetssjukehus og Institutt for helse og samfunn, Det medisinske fakultet, Universitetet i Oslo

\section{Anne Kathrine Langerud}

\section{Førsteamanuensis}

Institutt for sykepleie og helsefremmende arbeid, Oslomet og Akuttklinikken, Oslo universitetssykehus, Rikshospitalet

\section{Edda Johansen}

Førsteamanuensis og sykepleier Institutt for sykepleie- og helsevitenskap, Universitetet i Sørøst-Norge og Generell intensiv avdeling, Vestre Viken 


\section{Hovedbudskap}

Trykkskader kan i stor grad forebygges. Hensikten med denne fagartikkelen er å dele kunnskap om trykkskader og en skanner som er utviklet for å kunne identifisere tidlig vevsskade der ødem utvikles i underliggende vev, også kalt Sub-Epidermal Moisture (SEM). SEM-skanneren er et nyttig, spennende og innovativt innslag i norsk helsevesen. Verktøyet skal bidra til å identifisere vevsskader som ikke er visuelt synlige.

Hensikten med denne fagartikkelen er å dele kunnskap om trykkskader og en skanner som er utviklet for å kunne identifisere tidlig vevsskade i form av $\varnothing$ dem i underliggende vev, også kalt Sub-Epidermal Moisture (SEM).

Trykkskader, også kalt trykksår, liggesår og decubitus, oppstår hos personer som av ulike årsaker trenger bistand fra helsetjenesten.

Slike skader kan fremstå som en synlig skade på huden, men kan imidlertid også være skade på underliggende vev som ikke medfører perforasjon av huden. Internasjonale retningslinjer anbefaler derfor å benytte begrepet trykkskader fremfor trykksår (1).

\section{En trykkskade klassifiseres etter alvorlighet}

Trykkskader i huden eller underliggende fettvev og muskler oppstår gjerne over benfremspring primært på grunn av immobilitet eller som følge av trykk fra medisinsk utstyr (1). En synlig trykkskade i huden klassifiseres i henhold til alvorlighet, inkludert dybde, og vurderes fra hudens utside og innover (1).

Imidlertid kan skadene utvikles fra innsiden og utover uten at det nødvendigvis vises på huden tidlig i forløpet. En trykkskade er følgelig mer enn bare en synlig skade på huden (se figur 1) $(2,3)$. Tidlig oppdagelse av disse usynlige skadene er temaet i denne artikkelen.

Trykkskader kan i stor grad forebygges (1), ikke minst hvis de usynlige skadene under huden kan oppdages tidlig og skadene kan reverseres. Teknologi kan nå identifisere en tidlig skade med $\varnothing$ kt presisjon. Dermed er det mulig å komme tidlig i gang med forebygging og behandling, som kan gi både personlig og samfunns $\varnothing$ konomisk gevinst. 


\section{Hud og vev utsettes for trykk og skjærende krefter}

Når hud og vev utsettes for trykk, eller trykk i kombinasjon med skjærende krefter, er det flere og sammensatte prosesser som til slutt gir en trykkskade (1).

Vev som deformeres, skader cellene direkte. Det gir celledød med påfølgende inflammatoriske prosesser samt lokalt $\varnothing$ dem (2). Det lokale $\varnothing$ demet som oppstår under huden, kalles SEM.

Trykk og skjærende krefter kan i tillegg redusere eller hindre blodtilførselen til huden og vevet. Det reduserer tilførselen av oksygen - iskemi - samt næringsstoffer og gir opphopning av avfallsstoffer (2).

Når trykk og/eller skjærende krefter fjernes, oppstår en situasjon der vevet blir tilført disse avfallsstoffene - reperfusjon. Det trigger inflammasjonsprosessen ytterligere, cellene skades mer, og det ender til slutt i celledød.

Figur 1 gir en skjematisk fremstilling av prosessen som fører til celleskade, celled $\varnothing \mathrm{d}, \varnothing \mathrm{dem}$ og trykkskade.

Figur 1. Skjematisk oversikt over prosessen som fører til celledød og varig trykkskade

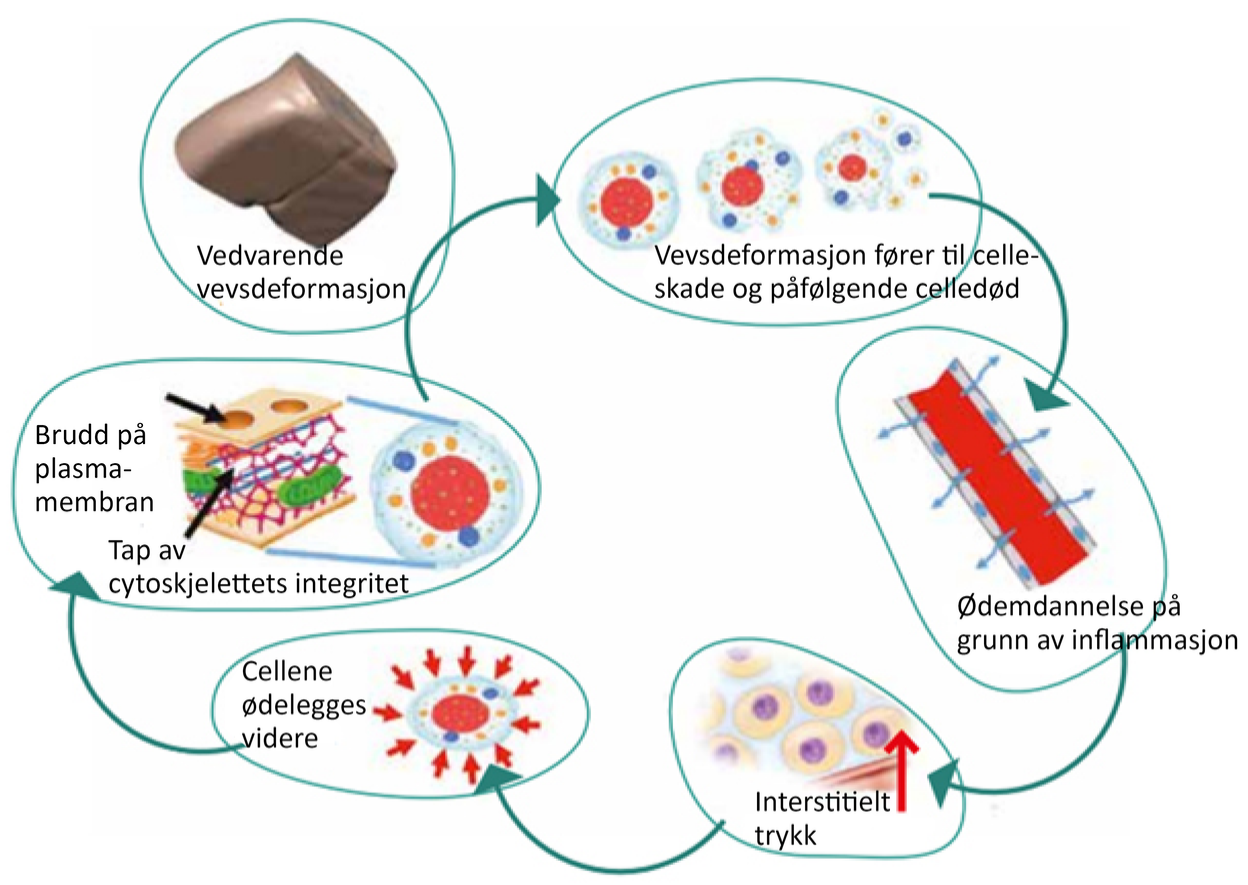

Kilde: Gefen (3), oversatt til norsk med tillatelse.

Laboratorieunders $\varnothing$ kelser har vist at en celledeformasjon gir varig skade etter få minutter, men det kan ta opptil flere dager før skaden er synlig for det blotte øyet (2). 
Tidlig identifisering av begynnende vevsskade, ved tidlig identifisering av trykkskaderelatert $\varnothing \mathrm{dem}$ i underliggende vev, vil derfor være viktig for å forebygge eller reversere videre utvikling av trykkskaden.

\section{Risikopasienter må identifiseres}

Enkelte pasientgrupper har høyere risiko enn andre. Forskning i Norge viser en trykksårforekomst på 10-20 prosent blant inneliggende personer på sykehus og sykehjem (7-9). Disse tallene dokumenterer nødvendigheten av forebyggende tiltak.

Noen av de viktigste tiltakene for å forebygge trykkskader er å identifisere risikopasienter, avklare risikofaktorer og iverksette hensiktsmessige forebyggende tiltak (1). Forskere har utviklet ulike numeriske og ikke-numeriske risikovurderingsinstrumenter, men ingen av disse har så langt vist seg å være optimale for å avdekke risiko (4).

I Norge benyttes foreløpig oftest en kombinasjon av en ikke-numerisk tilnærming og en klinisk vurdering i risikokartleggingen (5). Risikovurdering basert på klinisk vurdering vil alltid være subjektiv samt avhengig av helsepersonells erfaringer og kunnskap så vel som holdninger til å forebygge trykkskader $(4,6)$.

\section{SEM-skanneren kan måle ødem}

Ved hjelp av tilgjengelig teknologi har vi nå muligheten til å unders $\varnothing \mathrm{ke} \varnothing \mathrm{dem}$ som følge av trykk og skjærende krefter i underliggende vev, selv om dette vevet befinner seg under intakt hud.

\section{«De elektriske egenskapene under huden endres når det oppstår lokale ødem som følge av trykk og skjærende krefter.»}

Et verktøy som kan bidra til at helsepersonell i ulike sektorer identifiserer vevsskader som ikke er visuelt synlige, er et nyttig, spennende og innovativt innslag i norsk helsevesen. I retningslinjen fra 2019 (1) anbefaler EPUAP, NPIAP og PPPIA bruk av SEM-skanning som et supplement til klinisk vurdering.

SEM-skanneren måler de lokale elektriske egenskapene relatert til humant vev, også kalt bioimpedansen, over benfremspring under huden (10). De elektriske egenskapene under huden endres når det oppstår lokale ødem som følge av trykk og skjærende krefter. 
Det er dette $\varnothing$ demet, sammen med endringer i de elektriske egenskapene til skadet vev, som SEM-skanneren kan oppdage før trykkskaden er visuelt synlig på hudoverflaten (10, 11).

\section{Slik brukes SEM-skanneren}

SEM-skanneren er et håndholdt apparat (se figur 2).

\section{Figur 2. Skanner}

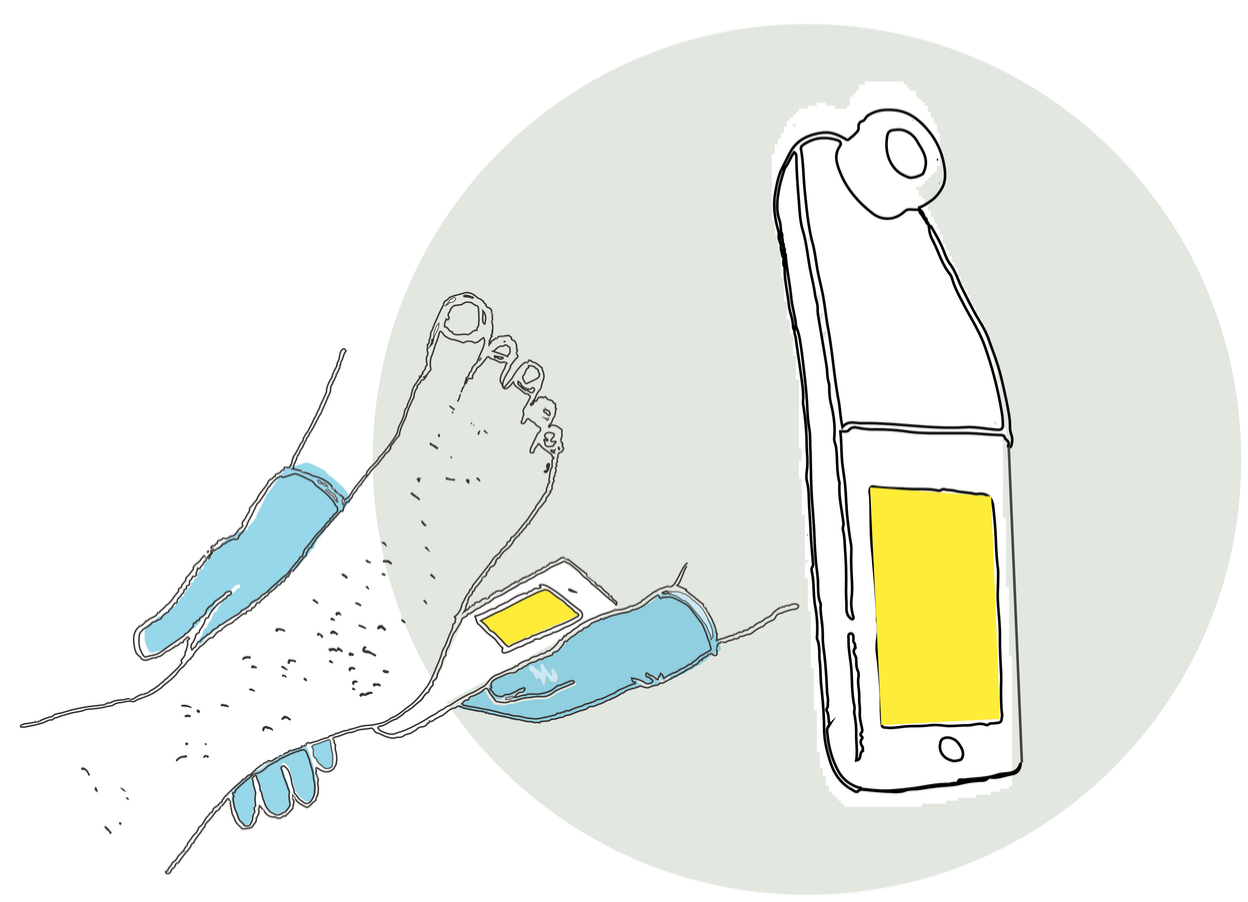

Skanneren holdes lett mot huden på områdene på kroppen som er godkjent for skanning.

Skanneren er foreløpig godkjent for bruk på hæler og sakrum eller korsbein, som er områder der en stor andel av trykkskader oppstår (12).

SEM-skanning skal gjennomføres én gang daglig, eller oftere ved behov, på de kroppsområdene den er godkjent for å unders $\varnothing$ ke. Produsenten anbefaler at skanningen gjennomføres $\mathrm{i}$ henhold til instruksjonen som er beskrevet for de spesifikke kroppsområdene (13).

Skanneren er et ikke-invasivt apparat, som holdes lett mot huden i en gitt rekkefølge i definerte områder (se figur 3 og 4). Den er kun i kontakt med intakt hud i en kort periode, og det er ikke rapportert uønskede hendelser ved å bruke utstyret (10).

Selve apparatet rengjøres i henhold til lokale prosedyrer som for annet flerbruksutstyr, for eksempel øretermometer og blæreskanner, og sensoren skiftes mellom hver pasientskanning. 


\section{SEM delta kan beskrive vevsendringer}

SEM delta $(\Delta)$ brukes for å beskrive de oppståtte vevsendringene. SEM $\Delta$ er forskjellen mellom individuelle målinger fra områder med $\varnothing \mathrm{kt} \varnothing \mathrm{dem}$ på grunn av trykk og/eller skjærende krefter og målinger fra nære ikke-affiserte områder (10). Det vil si at både antatt friskt og potensielt skadet vev over benfremspring skal unders $\varnothing$ kes $(10,13)$.

For sakrum beregnes en gjennomsnittlig SEM $\Delta$ ut fra skanning på seks ulike lokalisasjoner, mens det for hver hæl gjøres en beregning fra skanning på fire ulike steder (se figur 3 og 4 ).

\section{SEM delta $(\Delta)$}

SEM $\Delta$ = måling av forskjellen på affisert område og ikke-affisert område

SEM $\Delta \geq 0,6$ indikerer $\varnothing \mathrm{kt}$ risiko for skade i underliggende vev (10).

Figur 3 og 4 gir en veiledning i gjeldende anbefalinger for kroppsområder og rekkefølgen av områdene som skal unders $\varnothing$ kes.

Figur 3. Gjeldende anbefaling for områder som skal undersøkes på hælene
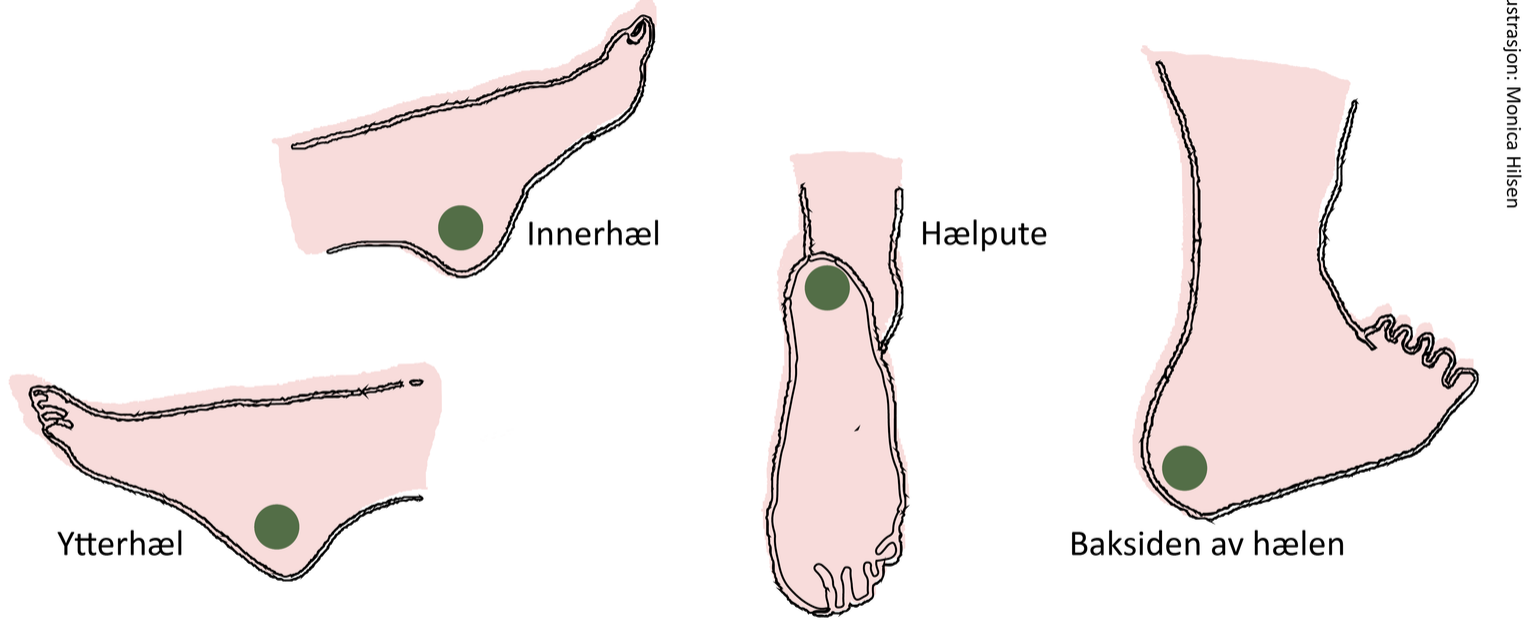


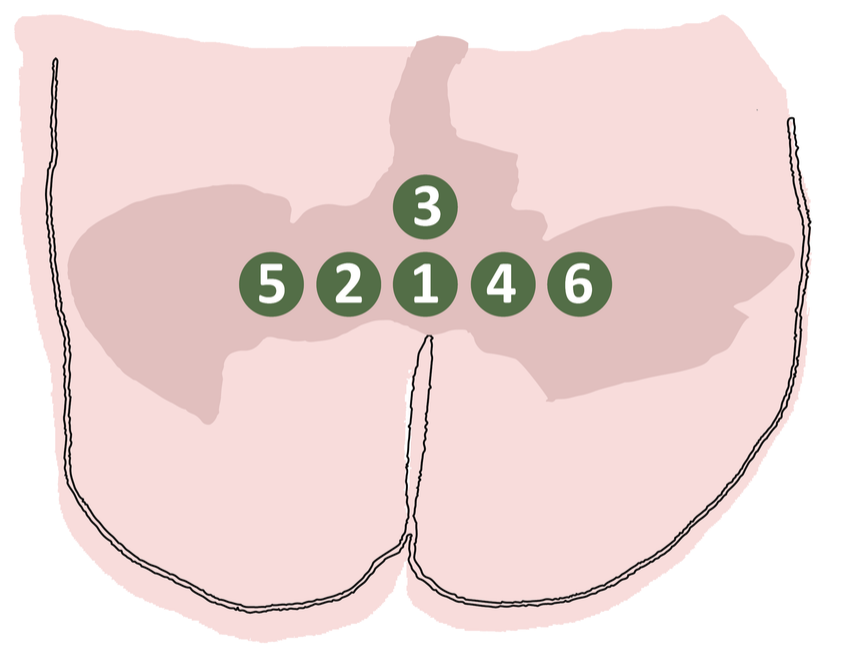

Kilder: Bruin Biometrics (13) og Musa med medarbeidere (14).

\section{Forekomsten av trykkskader er redusert}

Studier på SEM-skanning har pågått i mange år (10). Flere typer skannere kan oppdage SEM, og det foreligger en del kunnskap om effekten, men de fleste skannere er kun godkjent til forskningsøyemed (10). De studiene er ikke inkludert i denne artikkelen.

Her fokuserer vi kun på studier av skanneren som er godkjent for klinisk bruk, altså CE-merket og godkjent av Food and Drug Administration (FDA) (13), samt kommersielt tilgjengelig på det norske markedet.

Bruk av SEM-skannere kan gi en betydelig reduksjon i trykksår hos pasienter i institusjoner $(14,15)$. Studier av SEM-skannere som er benyttet på personer med tverrsnittlammelser innenfor fagområdene ortopedi og intensivavdelinger på sykehus samt på sykehjem og i hjemmebaserte tjenester, er spesielt interessante.

Dette er områder hvor pasienter har høy risiko for å utvikle trykkskader. En nylig studie med 1478 personer fra England viste at ti av 15 avdelinger med høyrisikopasienter reduserte forekomsten med 100 prosent, fra o,6 prosent og 8,3 prosent til o, over en periode på en til seks måneder etter å ha inkludert SEMskanner i risikovurderingen.

\section{«Bruk av SEM-skannere kan gi en betydelig reduksjon $\mathrm{i}$ trykksår hos pasienter i institusjoner.»}


De andre fem avdelingene kunne også dokumentere en redusert forekomst av trykkskader på mellom 26,7 prosent og 82,4 prosent (14). En svakhet ved denne studien er imidlertid forskjellen i datakvalitet på før- og ettertallene samt tidsintervallene i pre- og postoppfølging.

Studien samlet inn data fra ulike steder over en tidsperiode på seks år, men noen av studiestedene hadde likevel en oppfølgingstid på bare én måned.

Det kan heller ikke utelukkes at resultatene er påvirket av en såkalt Hawthorneeffekt, hvor forbedringen skjer fordi det pågår en studie (14). I en annen studie brukte Raizman og medarbeidere SEM-skanner for å se på igangsetting av forebyggende tiltak i to ulike perioder ved et sykehus i Canada (15).

Forskerne fant en nedgang i trykkskadeforekomsten fra 13,5 prosent (12 av 89) til 1 prosent (2 av 195). De fant også at tiltak ble igangsatt for flere personer når SEMskanning ble brukt i tillegg til standard risikovurdering, versus tiltak som var basert på kun en klinisk vurdering.

En svakhet ved denne studien er imidlertid at resultatene baseres på sammenlikning av to ulike utvalg i de to periodene. Funnene er derfor ikke direkte sammenliknbare (15).

\section{Trykkskade oppdages tidligere}

I en prospektiv studie om SEM-skanner på medisinsk-kirurgiske sykehusavdelinger i Irland ble 40 prosent (19 av 47) av trykkskadene oppdaget i gjennomsnitt fire dager før skaden var synlig på huden. Trykkskaden var visuelt synlig etter fem og en halv dag, mens skanneren oppdaget vevsendringer etter en og en halv dag (16).

En annen studie, som besto av 150 eldre deltakere, beregnet muligheten for å oppdage trykkskader med bruk av skanner til å være betydelig bedre. Hele 118 av de 150 unders $\varnothing$ kte fikk påvist vevsendringer med skanneren sammenliknet med visuell identifisering, hvor sår ble oppdaget hos 19 av de 150 unders $\varnothing$ kte.

Oddsen for at en skade blir oppdaget, er 25 ganger høyere med en SEM-skanner sammenliknet med visuell identifisering (17). Skanneren avdekket i tillegg vevsendringene i gjennomsnitt åtte dager tidligere enn hva som var tilfellet når den synlige skaden ble avdekket (17).

\section{SEM-skanneren oppdager de fleste trykkskader}


Flere studier har unders $\varnothing \mathrm{kt}$ SEM-skanneren relatert til sensitivitet: den identifiserer de som faktisk har trykkskade, og spesifisitet: de som ikke har trykkskade, registreres ikke. Studier har funnet at SEM-skanneren har en sensitivitet på mellom $82 \mathrm{og} 100$ prosent $(16,18,19)$, noe som er tilfredsstillende. Det viser at skanneren oppdager de fleste trykkskader.

Spesifisiteten viser seg imidlertid å være noe lavere, 33-88 prosent, i de samme studiene. Lav spesifisitet vil si at skanneren registrerer vevsforandringer og underliggende ødem som ikke utvikles til å bli til en reell trykkskade, altså falsk positiv måling.

Imidlertid har skanneren en bedre treffsikkerhet enn hva som var tilfellet med visuell registrering, da klinisk vurdering alene har vist å ha en sensitivitet på 50 prosent og en spesifisitet på 60 prosent (20).

Det betyr at skanneren er god for å oppdage de som faktisk har vevsforandringer som utvikles til trykkskade, men at den også registrerer vevsforandringer som ikke utvikles til trykkskader.

Det betyr igjen at bruk av skanneren kan medføre at forebyggende tiltak blir satt i gang uten at det er nødvendig. Ut over dette har imidlertid ikke skanneren vist å ha uheldige bivirkninger for personene som er skannet.

$\AA$ bruke en SEM-skanner kombinert med en klinisk vurdering $\varnothing$ ker dermed muligheten for å kunne skille mellom personer i risiko og ikke sammenliknet med kun visuell vurdering i kombinasjon med risikoscreeningsverktøyene som er i bruk per i dag. Vi kan ikke observere underliggende $\varnothing$ dem, slik skanneren gjør.

\section{Andre funn og fordeler med SEM-skanner}

Bruk av skanneren kan tilrettelegge for en mer hensiktsmessig bruk av tilgjengelig trykkskadeforebyggende utstyr, som spesialmadrasser og senger.

Skanneren kan bidra til økt bevisstgjøring av risiko og dermed hensiktsmessig igangsetting av forebyggende tiltak (14). Det vil komme pasientene til gode ved at det blir skjerpet oppmerksomhet på forebyggende tiltak, og uønsket variasjon unngås.

\section{Få studier har vurdert kostnadseffektivteten}

Nåværende kunnskap tilsier at det er rimeligere å forebygge enn å behandle trykkskader (21). Utenlandske studier viser at kostnadene ved å behandle et trykksår kan koste nær 5000 kroner per person per dag, avhengig av sårets tilstand og situasjonen pasienten befinner seg i. 
For forebygging var det høyeste beløpet cirka 1000 kroner per person per dag, men også dette var avhengig av situasjonen personen var i (21).

Det er hittil få studier som har sett på kostnadseffektiviteten ved å bruke SEMskanner $(22,23)$. En studie så på bruk av SEM-skanner i tillegg til eksisterende rutiner for å forebygge trykkskader (22).

Studien viste at SEM-skanning reduserte variasjon i risikovurdering, og at den ga en mer målrettet bruk av tiltak samt en reduksjon i uønskede hendelser, som reinnleggelser og dødsfall relatert til institusjonservervede trykkskader (22). Studien viste en potensiell besparelse på 4054 amerikanske dollar, tilsvarende 34 ooo kroner per akutte innleggelse (22).

\section{«Nåværende kunnskap tilsier at det er rimeligere å forebygge enn å behandle trykkskader.»}

En annen studie fant en estimert besparelse per år når SEM-skanning ble brukt, på ca. 0,6-3,3 millioner britiske pund for sykehus med rundt 40000 innleggelser avhengig av hvilken trykksårinsidens de regnet ut ifra (1,6-6,3 prosent) (23).

Besparelsene kommer blant annet av at en større andel ikke synlige vevsskader og kategori 1-trykkskader ble oppdaget, slik at videre utvikling kan snus med relativt enkle grep. I tillegg vil en unngå å implementere unødvendige tiltak hos de som ikke er i risiko (23). Dette gir både en individuell og en samfunnsøkonomisk gevinst.

Produsenten har vært involvert i begge $\varnothing$ konomistudiene, og det kan ha medvirket til skjevhet i analyseresultatene, altså bias. Studiene er modellerte, som vil si at tallene er matematisk beregnet, og ikke hentet fra reelle studier utført på mennesker.

$\AA$ kjøpe inn nytt utstyr og ny teknologi er ofte dyrt. I tillegg kreves det tid til opplæring og implementering. I det lange løp er det likevel trolig kostnadseffektivt ved at utgifter knyttet til behandling av trykkskader, kan bli redusert.

\section{Studiene om SEM-skannere har noen svakheter}

Studiene av SEM-skannere som denne artikkelen viser til, har imidlertid en del svakheter. Studiene er utført i land med et annet helse- og økonomistyringssystem enn Norge. Det gjør at funnene ikke nødvendigvis er direkte sammenliknbare med norske forhold. 
Det er dessuten kun skanning av hæler og sakrum eller korsbein som er sikre områder med dagens skanner. Det er gjort studier med skanning av andre trykkutsatte steder, men disse funnene er mer usikre (24). Dette er en stor ulempe, da det er behov for verktøy som også kan skanne andre kroppslokalisasjoner, for eksempel sitteknutene.

SEM-skanneren kan heller ikke identifisere dybde på skade eller $\varnothing \mathrm{dem}$, noe som begrenser effekten av å kunne identifisere dybden på de mistenkt dype vevsskadene (21). Det er også mangel på studier som vurderer effekten over lengre tid, samt at det mangler publiserte resultater fra randomisert kontrollerte studier.

I tillegg er det behov for studier som inkluderer pasientrapporterte utfallsmål. Sist, men ikke minst, mangler det kost-nytte-studier som er utført i reelle pasientsettinger (21-23).

\section{Oppsummering}

Trykkskader kan i stor grad forebygges, ikke minst hvis de usynlige skadene i form av $\varnothing$ dem i vevet under hudlaget kan oppdages tidlig og dermed reverseres. Den omtalte SEM-skanneren, og kommende tilsvarende apparater, kan være et viktig bidrag til å kunne gjennomføre en god og objektiv vurdering av potensiell trykkskadeutvikling.

En tidligere identifisering av begynnende skader vil bidra til en mer målrettet iverksetting av forebyggende tiltak og slik bidra til en mer hensiktsmessig fordeling av ressursene. Det er imidlertid behov for gode studier i en norsk kontekst for å få hensiktsmessig kunnskap om pasienters så vel som samfunns $\varnothing$ konomiske effekter ved å bruke skanneren.

Det foreligger ingen bindinger mellom forfatterne av artikkelen og firmaet som distribuerer SEM-skanneren $i$ Norge.

\section{Referanser}

1. EPUAP, NPIAP, PPPIA. Prevention and treatment of pressure ulcers/injuries: clinical practice guideline. The international guideline. EPUAP, NPIAP, PPPIA; 2019. Tilgjengelig fra: https://www.internationalguideline.com/ (nedlastet 17.01.2022).

2. Gefen A, Brienza DM, Cuddigan J, Haesler E, Kottner J. Our contemporary understanding of the aetiology of pressure ulcers/pressure injuries. Int Wound J. 2021;19(3). DOI: 10.1111/iwj.13667 
3. Gefen A. The future of pressure ulcer prevention is here: detecting and targeting inflammation early. EWMA J. 2018;19(2):7-13. Tilgjengelig fra: https://ewma.org/fileadmin/user_upload/EWMA.org/EWMA_Journal/articles_previ ous_issues/Gefen_A.pdf (nedlastet 19.07.2021).

4. Moore ZE, Patton D. Risk assessment tools for the prevention of pressure ulcers. Cochrane Database Syst Rev. 2019;1(1):CDoo6471. DOI: 10.1002/14651858.CDoo6471.pub4

5. Johansen E. The 3-risk approach to pressure ulcer assessment in Norway safe or a risky business? Wounds UK. 2017;13(4):50-4.

6. Parisod H, Holopainen A, Kielo-Viljamaa E, Puukka P, Beeckman D, Haavisto E. Attitudes of nursing staff towards pressure ulcer prevention in primary and specialised health care: a correlational cross-sectional study. Int Wound J. 2022;19(2):399-410. DOI: 10.1111/iwj.13641

7. Bredesen IM, Bjoro K, Gunningberg L, Hofoss D. The prevalence, prevention and multilevel variance of pressure ulcers in Norwegian hospitals: a cross-sectional study. Int J Nurs Stud. 2015;52(1):149-56. DOI: 10.1016/j.jinurstu.2014.07.005

8. Hansen RL, Fossum M. Nursing documentation of pressure ulcers in nursing homes: comparison of record content and patient examinations. Nursing Open. 2016;3(3):159-67. DOI: 10.1002/nop2.47

9. Skogestad IJ, Martinsen L, Borsting TE, Granheim TI, Ludvigsen ES, Gay CL, et al. Supplementing the Braden scale for pressure ulcer risk among medical inpatients: the contribution of self-reported symptoms and standard laboratory tests. J Clin Nurs. 2017;26(1-2):202-14. DOI: 10.1111/jocn.13438

10. Bryant RA, Moore ZE, Iyer V. Clinical profile of the SEM scanner modernizing pressure injury care pathways using sub-epidermal moisture (SEM) scanning. Expert Rev Med Devices. 2021;18(9):833-47. DOI.

$\underline{10.1080 / 17434440.2021 .1960505}$

11. Moore Z, Patton D, Rhodes SL, O'Connor T. Subepidermal moisture (SEM) and bioimpedance: a literature review of a novel method for early detection of pressure-induced tissue damage (pressure ulcers). Int Wound J. 2017;14(2):331-7. DOI: 10.1111/iwj.12604 
12. Moore Z, Avsar P, Conaty L, Moore DH, Patton D, O'Connor T. The prevalence of pressure ulcers in Europe, what does the European data tell us: a systematic review. J Wound Care. 2019;28(11):710-9. DOI:

$\underline{10.12968 / \text { jowc.2019.28.11.710 }}$

13. Bruin Biometrics. SEM scanner PS. Cheshire: Bruin Biometrics; u.å. Tilgjengelig fra: https://sem-scanner.com/ (nedlastet 09.09.2021).

14. Musa L, Ore N, Raine G, Smith G. Clinical impact of a sub-epidermal moisture scanner: what is the real-world use? J Wound Care. 2021;30(3):198-208. DOI: 10.12968/jowc.2021.30.3.198

15. Raizman R, MacNeil M, Rappl L. Utility of a sensor-based technology to assist in the prevention of pressure ulcers: a clinical comparison. Int Wound J. 2018;15(6):1033-44. DOI: 10.1111/iwj.12974

16. O'Brien G, Moore Z, Patton D, O'Connor T. The relationship between nurses' assessment of early pressure ulcer damage and sub epidermal moisture measurement: a prospective explorative study. J Tissue Viability. 2018;27(4):232-7.

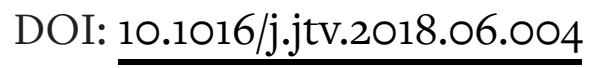

17. Budri AMV, Moore Z, Patton D, O'Connor T, Nugent L, Mc Cann A, et al. Impaired mobility and pressure ulcer development in older adults: excess movement and too little movement-two sides of the one coin? J Clin Nurs. 2020;29(15-16):2927-44. DOI: $10.1111 /$ jocn.15316

18. Gershon S, Okonkwo H. Evaluating the sensitivity, specificity and clinical utility of algorithms of spatial variation in sub-epidermal moisture (SEM) for the diagnosis of deep and early-stage pressure-induced tissue damage. J Wound Care. 2021;30(1):41-53. DOI: 10.12968/jowc.2021.30.1.41

19. Okonkwo H, Bryant R, Milne J, Molyneaux D, Sanders J, Cunningham G, et al. A blinded clinical study using a subepidermal moisture biocapacitance measurement device for early detection of pressure injuries. Wound Repair Regen. 2020;28(3):364-74. DOI: $10.1111 /$ wrr.12790

20. Pancorbo-Hidalgo PL, Garcia-Fernandez FP, Lopez-Medina IM, Alvarez-Nieto C. Risk assessment scales for pressure ulcer prevention: a systematic review. J Adv Nurs. 2006;54(1):94-110. DOI: 10.1111/j.1365-2648.2006.03794.x

21. Demarré L, Van Lancker A, Van Hecke A, Verhaeghe S, Grypdonck M, Lemey $\mathrm{J}$, et al. The cost of prevention and treatment of pressure ulcers: a systematic review. Int J Nurs Stud. 2015;52(11):1754-74. DOI: 10.1016/j.ijnurstu.2015.06.006 
22. Padula WV, Malaviya S, Hu E, Creehan S, Delmore B, Tierce JC. The costeffectiveness of sub-epidermal moisture scanning to assess pressure injury risk in US health systems. Journal of Patient Safety and Risk Management. 2020;25(4):14755. DOI: $\underline{10.1177 / 2516043520914215}$

23. Gefen A, Kolsi J, King T, Grainger S, Burns M. Modelling the cost-benefits arising from technology-aided early detection of pressure ulcers. Wounds Int. 2020;11(1):12-7.

24. Jayabal H, Bates-Jensen BM, Abiakam NS, Worsley PR, Bader DL. Anatomical variability of sub-epidermal moisture and its clinical implications. J Tissue Viability. 2021;30(3):434-8. DOI: 10.1016/j.jtv.2021.04.003

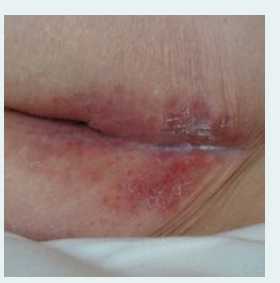

\section{LES OGSÅ}

Er det fuktskadet hud eller trykksår?

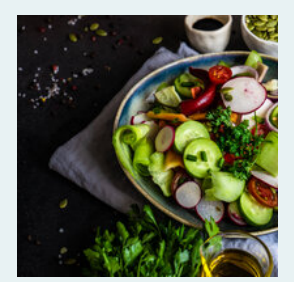

\section{LES OGSA}

God sykepleie gir færre komplikasjoner ved diabetes type 2

\section{LES OGSÅ}

Bruk verktøyet TIMES til å vurdere sår strukturert 